\title{
PEMANFAATAN DAUN RAMI SEBAGAI BAHAN ZAT WARNA ALAM DAN FUNGSIONALISASINYA PADA PENCELUPAN KAIN KAPAS DAN SUTERA
}

\author{
UTILIZATION OF RAMIE LEAVES AS A NATURAL DYE AND ITS \\ FUNCTIONALIZATION FOR DYEING COTTON AND SILK FABRIC
}

\author{
Jakariya Nugraha, Emma Yuniar Rakhmatiara \\ Balai Besar Tekstil, Jalan Jenderal Ahmad Yani No. 390 Bandung \\ Email: jaka@kemenperin.go.id
}

Tanggal diterima: 19 Maret 2020, direvisi: 8 Juni 2020, disetujui terbit: 8 Juni 2020

\begin{abstract}
ABSTRAK
Ekstrak daun rami dapat dimanfaatkan sebagai bahan zat warna alam pada proses pencelupan tekstil karena mengandung senyawa flavonoid. Dalam penelitian ini telah dilakukan studi tentang pencelupan kain kapas dan sutera dengan zat warna alam dari hasil ekstraksi daun rami. Studi ini bertujuan untuk mempelajari kemungkinan pemanfaatan daun rami sebagai zat warna alam dan sebagai zat anti oksidan pada tekstil. Metode penelitian meliputi ekstraksi daun rami, pencelupan metode perendaman dan post-mordanting. Evaluasi kualitas hasil pencelupan meliputi ketuaan warna $(\mathrm{K} / \mathrm{S})$, kecerahan warna $\left(\mathrm{L}^{*}\right)$, arah warna $\left(\mathrm{a}^{*}, \mathrm{~b}^{*}\right)$, ketahanan luntur warna terhadap pencucian, gosokan, dan cahaya, serta pengujian proteksi kain terhadap sinar UV atau Ultraviolet Protection Factor (UPF). Hasil penelitian menunjukkan bahwa ekstrak daun rami dapat mencelup bahan tekstil dengan ketuaan warna pada sutera lebih baik daripada kain kapas. Kecerahan warna berbanding terbalik dengan ketuaan warna, dan arah warna yang dihasilkan adalah merah dan kuning. Kualitas pencelupan memiliki ketahanan luntur terhadap pencucian dengan nilai perubahan warna untuk kapas 3-4 dan sutera 4, sedangkan penodaan warna untuk kedua kain tersebut 4-5. Nilai penodaan warna karena gosokan bervariasi dari 3-4, 4, dan 4-5 pada masing-masing kain sampel dengan gosokan kering lebih baik daripada gosokan basah. Nilai ketahanan luntur warna terhadap sinar matahari relatif buruk yaitu 2 untuk kain kapas dan 2-3 untuk kain sutera, namun pada kain yang di post-mordanting menggunakan $\mathrm{FeSO}_{4}$ mempunyai nilai tiga tingkat lebih tinggi daripada variasi lainnya. Pencelupan dengan zat warna hasil ekstraksi daun rami menggunakan bahan post-mordanting $\mathrm{FeSO}_{4}$ efektif meningkatkan nilai UPF hingga UPF 10,6 pada kain kapas dan UPF 25 untuk kain sutera.
\end{abstract}

Kata kunci: ekstrak daun rami, flavonoid, pencelupan, UPF

\begin{abstract}
Ramie leaves extract can be used as a natural dye in textile dyeing process because it contains flavonoid compounds. This research activity has been carried out on the dyeing of cotton and silk fabrics with natural dye from the extraction of ramie leaves. This study aims to study the possibility of utilizing ramie leaves as a natural dye and antioxidant in textiles. Research methods include ramie leaves extraction, dyeing, and post-mordanting methods. Evaluation of the quality of dyeing results includes color aging $(K / S)$, color brightness $\left(L^{*}\right)$, color direction $\left(a^{*}, b^{*}\right)$, colorfastness to washing, rubbing, light, and testing of clothing protection against UV or Ultraviolet Protection Factor (UPF). The results showed that ramie leaves extract could dye textiles with color aging on silk better than cotton cloth. Brightness is inversely proportional to the color aging, and the direction of the resulting color is red and yellow. Dyeing quality has colorfastness to washing with color change values for cotton 3-4 and silk 4, while the color stain for both fabrics is 4-5. Color staining value due to rubbing varies from 34, 4, and 4-5 on each sample cloth with a dry rub is better than a wet rub. The amount of colorfastness to sunlight is relatively weak, namely 2 for cotton cloth and 2-3 for silk cloth, but the fabric fixed using FeSO4 has a value three levels higher than other variations. Dyeing with dyes from the extract of ramie leaves with $\mathrm{FeSO}_{4}$ mordant is effective in increasing the UPF value up to UPF 10,6 for cotton fabrics and UPF 25 for silk fabrics.
\end{abstract}

Keywords: ramie leaves extract, flavonoids, dyeing, UPF. 


\section{PENDAHULUAN}

Indonesia memiliki keanekaragaman hayati yang sangat banyak dan dapat dimanfaatkan oleh manusia, salah satunya adalah rami. Tanaman Rami (Boehmeria Nivea) merupakan salah satu tanaman yang sudah dimanfaatkan oleh manusia setidaknya sejak 6000 tahun lalu. ${ }^{1}$ Bagian yang dimanfaatkan pada tanaman rami adalah batang dan daunnya. Batang rami berpotensi digunakan sebagai bahan baku pembuatan pulp dan kertas, produk tekstil dan tekstil teknik, serta komposit. ${ }^{2,3,4,5}$ Sektor tekstil menjadi salah satu sektor yang memanfaatkan tanaman rami sebagai bahan baku. Serat tersebut dihasilkan dari kulit kayu tanaman rami dengan cara dekortikasi. Akan tetapi, sebagai bahan baku tekstil hanya $5 \%$ bagian dari keseluruhan tanaman rami saja yang digunakan. ${ }^{6}$ Berdasarkan data yang dilaporkan oleh Djumali pada Sudibyo (2004) dalam setiap hektare tanaman rami yang dipanen dapat menghasilkan limbah daun rami kering sebanyak 6 ton. $^{7}$ Dengan demikian perlu adanya alternatif pemanfaatan yang perlu dilakukan guna meningkatkan nilai tambah limbah daun rami.

Di Indonesia, limbah daun rami tersebut dimanfaatkan sebagai pakan ternak domba. Hal tersebut berdasar karena daun rami memiliki kandungan protein yang cukup tinggi sebesar $24 \%$ sehingga jika digunakan sebagai pakan ternak akan meningkatkan efisiensi biaya pakan. ${ }^{8}$ Selain untuk pakan ternak, dilaporkan bahwa ekstrak daun rami mengandung berbagai macam kandungan yang sangat bermanfaat sebagai anti oksidan, anti kanker, anti mikroba, dan penurun kadar glukosa. ${ }^{9,10}$ Salah satu senyawa yang terkandung dalam daun rami adalah flavonoid. Flavonoid merupakan senyawa yang terdiri dari 15 atom karbon yang berfungsi sebagai pigmen tanaman serta dapat larut dalam pelarut polar seperti etanol, metanol, butanol, aseton, dimetil sulfoksida (DMSO), dimetil formamida (DMF), air, dan lain-lain..$^{11,12}$

Daun rami kaya akan senyawa fenolik dan flavonoid. Berdasarkan laporan Lee (2015) pada ekstrak daun rami dari perkebunan Geumsanmyeon Korea terkandung total flavonoid sebanyak $12,438 \pm 0,413 \mathrm{mg} / \mathrm{g}$ dengan komposisi, 12,205 \pm $0,355 \mathrm{mg} / \mathrm{g}$ quercatin, $0,233 \pm 0,011 \mathrm{mg} / \mathrm{g}$ epicatechin gallate, dan $0,138 \pm 0,047 \mathrm{mg} / \mathrm{g}$ epicatechin. ${ }^{13}$ Pada jurnal lain, dituliskan bahwa kandungan kimia dari ekstrak daun rami terdiri dari $132,5 \pm 2,76 \mathrm{mg} / \mathrm{g}$ total polifenol, $119 \pm 1,15 \mathrm{mg} / \mathrm{g}$ total flavonoid, dan 15,24 $\pm 0,65 \mathrm{mg} / \mathrm{g}$ asam klorogenik. ${ }^{6} \quad$ Sementara itu Chen (2014) melaporkan kandungan fenolik bebas pada ekstrak daun rami sebesar 291,44 GAE/100g, flavonoid bebas sebanyak $116,34 \mathrm{mg}$ CAE/100g dan total asam klorogenik sebanyak 38,24 $\pm 2,15 \mathrm{mg} / 100 \mathrm{~g}$ berat segar daun rami. ${ }^{14}$ Adanya perbedaan kuantitas dari berbagai komponen kimia yang ada pada ekstrak daun rami ini disebabkan oleh metode pengerjaan dan sampel yang berbeda pula.

Flavonoid sudah dikenal sebagai salah satu sumber yang digunakan sebagai zat warna alam baik pada makanan maupun untuk tekstil. Zat warna alam dapat diperoleh dengan cara mengekstraksi bagian pada tanaman menggunakan pelarut yang sesuai kepolarannya dengan zat yang akan diekstrak. ${ }^{15}$ Pada proses pencelupan dan pencapan tekstil, zat warna alam digunakan sebagai bahan pewarna untuk produk tekstil. Penelitian tentang pencelupan dengan zat warna alam yang mengandung flavonoid sudah banyak dilakukan. Beberapa di antaranya, pencelupan kain wol dengan ekstrak teh yang dilakukan oleh Moiz dkk (2010). Moiz menggunakan metode aqueous extract dan fokus mempelajari hasil warna dari variasi penggunaan bahan post-mordanting. ${ }^{16}$ Berikutnya Mongkholrattanasit dkk (2011) yang mengesktrak daun ekaliptus menggunakan metode aqueos extract sebagai pewarna untuk mencelup kain kapas dan wol dengan teknik pad-dry. ${ }^{17}$ Rehman dkk (2013) menggunakan ekstrak bubuk kulit bawang sebagai sumber flavonoid alami (quarcetin) untuk mencelup kain kapas yang sudah diiradiasi oleh sinar gamma. ${ }^{18}$ Bagian dari tanaman sitrus seperti daun dan kulit buahnya juga diketahui mengandung senyawa flavonoid. Sanggetha dkk (2015) memanfaatkan ekstraksi daun lemon untuk mencelup kain sutera, sedangkan Kumar (2017) menggunakan kulit jeruk dan kulit lemon untuk diekstraksi sebagai bahan zat warna alam pada pencelupan kain kapas. ${ }^{19,20}$

Selain sebagai sandang, perkembangan teknologi tekstil saat ini mengarah pada pembuatan tekstil fungsional. Salah satunya adalah fungsionalisasi sifat anti UV pada bahan tekstil. Senyawa-senyawa anorganik semikonduktif berukuran nano seperti $\mathrm{TiO}_{2}$ dan $\mathrm{ZnO}$ diketahui menjadi senyawa yang mempunyai kemampuan mengabsorpsi sinar UV serta sudah diaplikasikan pada tekstil. Namun karena berukuran partikel kecil maka cenderung untuk beraglomerasi dan mengakibatkan tidak terdistribusi secara merata sehingga mengurangi efektivitas kinerjanya. Selain itu, aplikasi senyawa anorganik pada bahan tekstil tidak bersifat simultan dengan pencelupan. Proses yang dilakukan terpisah dengan pencelupan berpotensi merubah warna. ${ }^{21,22}$

Pemanfaatan senyawa bioaktif dari bahan alam bisa menjadi alternatif untuk dilakukan. Selain dapat menjadi sumber zat warna alami, bioaktif pada tanaman juga dapat menjadi zat finishing tertentu dengan satu kali proses pencelupan. Flavonoid dan senyawa fenolik lainnya diketahui sebagai zat anti oksidan yang dapat menghambat radikal bebas. Pada tanaman, flavonoid berperan melindungi tanaman dari radiasi sinar matahari UV 
dan menangkal UV yang dihasilkan oleh ROS (Reactive Oxygen Species).

Penelitian penggunaan bioaktif flavonoid dan senyawa fenolik lainnya dari bahan alam untuk meningkatkan kemampuan proteksi UV pada kain sudah banyak dilakukan. Beberapa diantaranya, Rungruangkitkrai (2013) mengevaluasi kemampuan proteksi UV pada kain wool hasil pencelupan menggunakan ekstrak daun ekaliptus dan berkesimpulan bahwa kain wool tersebut mempunyai kemampuan proteksi UV yang sangat baik. ${ }^{23}$ Zhou (2016) telah berhasil memperoleh kain sutera berkemampuan proteksi UV baik dengan mengaplikasikan baicilin dari tanaman bunga Scutellaria baicalensis Georgi menggunakan teknik pencelupan perendaman. ${ }^{24}$ Koh (2017) menyimpulkan bahwa kain wool yang dicelup dengan zat warna dari ampas kopi menunjukkan aktivitas anti oksidan dan mempunyai kemampuan menghalau UV..$^{25}$

Dari hasil studi literatur belum ada yang melaporkan penelitian tentang pemanfaatan daun rami sebagai zat warna alami untuk bahan tekstil. Penelitian ini bertujuan untuk mempelajari kemungkinan dua pemanfaatan daun rami pada proses tekstil. Pertama sebagai zat warna alam pada pencelupan kain kapas dan sutera. Kedua sebagai zat anti oksidan yang dapat meningkatkan proteksi bahan tekstil terhadap sinar UV sehingga diharapkan dapat menjadi salah satu alternatif dari pemanfaatan daun rami.

\section{METODE \\ Bahan}

Bahan yang digunakan pada percobaan ini terdiri dari dua jenis kain yang berbeda. Pertama, kain kapas $100 \%$ siap celup anyaman polos 1/1 dengan gramasi $121,68 \mathrm{~g} / \mathrm{m}^{2}$, tetal lusi 78 helai per inci, tetal pakan 74 helai per inci. Kain kedua adalah kain $100 \%$ sutera siap celup hasil produksi Silk Center BBT dengan gramasi $67,11 \mathrm{~g} / \mathrm{m}^{2}$, tetal lusi 86 helai per inci, tetal pakan 80 helai per inci. Daun tanaman rami berusia satu tahun. $\mathrm{Al}_{2}\left(\mathrm{SO}_{4}\right)_{3}$, $\mathrm{Ca}(\mathrm{OH})_{2}, \mathrm{FeSO}_{4}$, dan teepol dari Brataco Chemical.

\section{Peralatan}

Peralatan yang digunakan adalah perlengkapan gelas laboratorium (Iwaxi pyrex), hotplate (Heidolph), oven (Heraeus), timbangan (Chyo JL-180), Curing (Werner Mathis AG), spektrofotometer (X-Rite Color-i7), Lauder-Ometer (SDL Atlas), rubbing tester (SDL Atlas), panel color fastness to light, spektrofotometer UPF (JASCO, V-750).

Semua pengerjaan dilakukan di laboratorium Sarana Riset Kimia Tekstil dan laboratorium Pengujian Kimia Tekstil, Balai Besar Tekstil.

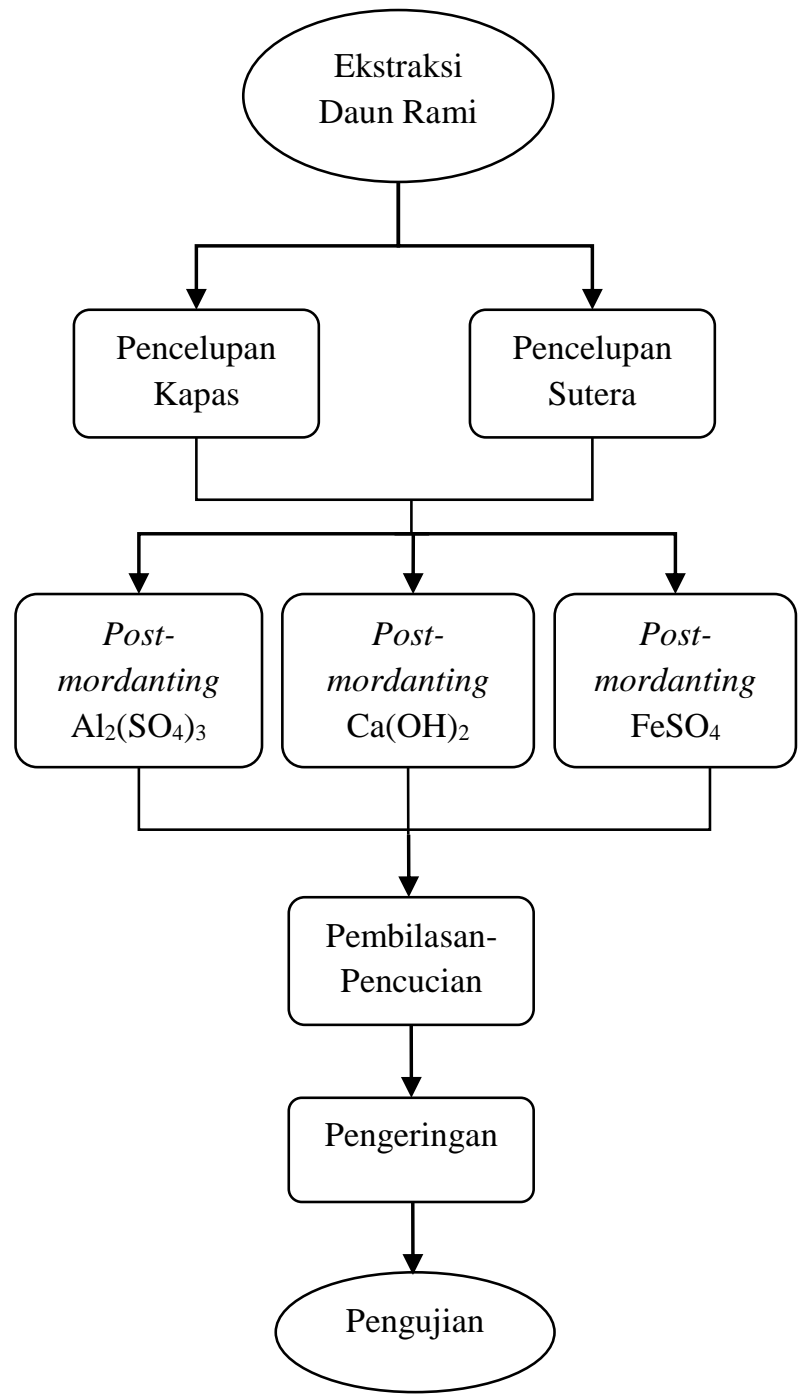

Gambar 1. Diagram alir metode penelitian

\section{Ekstraksi Zat Warna}

Pembuatan zat warna dari daun rami dilakukan dengan metode ekstraksi menggunakan air atau aqueous method. Proses ekstraksi daun rami dimulai dengan memotong-motong daun rami kemudian direndam dalam air dengan perbandingan 1:10 selama 1 jam pada suhu $100^{\circ} \mathrm{C}$. Larutan zat warna didinginkan dan disaring hingga tidak tersisa daun dan kotoran-kotoran lainnya.

\section{Pencelupan}

Proses pencelupan dengan menggunakan zat warna alam terdiri dari, pencelupan, postmordanting, dan pencucian pengeringan sebagaimana dapat dilihat pada Gambar 1.

a. Proses pencelupan pada kain kapas dilakukan pada suhu $80^{\circ} \mathrm{C}$ selama 30 menit dengan vlot 1:10. Pencelupan kain sutera dilakukan pada suhu kamar dengan vlot 1:10 selama 30 menit. Untuk mendapatkan hasil terbaik, pencelupan pada kedua sampel kain dikerjakan sebanyak 8 
kali dengan kondisi sama seperti sebelumnya (celup-bilas-impregnasi-celup). ${ }^{26}$

b. Post-mordanting zat warna alam pada percobaan ini menggunakan tiga jenis zat yang berbeda yaitu: $50 \mathrm{gr} / \mathrm{lll}_{2} \mathrm{Al}_{2}\left(\mathrm{SO}_{4}\right)_{3}, \quad 50 \mathrm{gr} / \mathrm{l}$ $\mathrm{Ca}(\mathrm{OH})_{2}, 50 \mathrm{gr} / \mathrm{FeSO}_{4}$. Kain hasil pencelupan direndam pada masing-masing larutan postmordanting selama 15 menit. Kain diimpregnasi dengan WPU 80\%, dibilas dan dicuci menggunakan teepol kemudian diimpregnasi kembali dan dikeringkan pada mesin pengering $100^{\circ} \mathrm{C}$ selama 3 menit.

\section{Pengujian}

Untuk mengetahui kualitas dari hasil celupan yang menggunakan zat warna daun rami pada kain kapas dan sutera dilakukan beberapa pengujian tekstil berdasarkan standar, yaitu: SNI-ISO 105-J03 2016 (Tekstil - Cara uji tahan luntur warna Bagian J03: Perhitungan beda warna), SNI-ISO 105-C06:2010 (Tekstil - Cara uji tahan luntur warna - Bagian C06: Tahan luntur warna terhadap pencucian rumah tangga dan komersil), SNI-ISO 105-X12:2001 (Tekstil - Cara uji tahan luntur Bagian X12: Tahan luntur warna terhadap gosokan), SNI-ISO 105-B01:2010 (Tekstil - Cara uji tahan luntur warna-Bagian B01: Tahan luntur warna terhadap sinar: Sinar terang hari). Untuk mengetahui fungsionalisasi pada kain sampel hasil pencelupannya, dilakukan pengujian sifat proteksi UV. Standar uji yang diacu adalah AS/NZS 4399: 2017) Sun protective clothing - Evaluation and classification.

\section{HASIL DAN PEMBAHASAN}

Analisis Uji Ketuaan (K/S), Kecerahan ( $\left.L^{*}\right)$, dan $\operatorname{Arah}\left(\mathbf{a}^{*}, \mathbf{b}^{*}\right)$

Ketuaan warna hasil pencelupan dapat diketahui dengan mengukur nilai reflektansi kain. Contoh uji diukur reflektansinya (\%R) pada panjang gelombang $360-700 \mathrm{~nm}$ dengan selang 10 $\mathrm{nm}$. Dari pengukuran nilai reflektansi pada panjang gelombang maksimumnya tersebut, kemudian dihitung nilai $\mathrm{K} / \mathrm{S}$ zat warna.

Perhitungan nilai K/S menggunakan persamaan (1) Kubelka-munk berikut ini

$$
K / S=\frac{(1-R)^{2}}{2 R}
$$

Keterangan:

$\mathrm{K}$ : Koefisien penyerapan cahaya

$\mathrm{S}$ : Koefisien penghamburan cahaya

R: \% reflektansi

$\mathrm{K} / \mathrm{S}$ zat warna diasumsikan setara dengan banyaknya zat warna yang terserap ke dalam kain. Semakin tinggi nilai K/S zat warna maka diasumsikan semakin banyak pula zat warna yang terserap ke dalam kain, sehingga warnanya semakin tua.

Tabel 1. Data nilai ketuaan warna pada kain sampel hasil pencelupan

\begin{tabular}{lcccc}
\hline Variasi & \multicolumn{3}{c}{ Nilai Ketuaan Warna pada $\lambda$ maks } \\
\cline { 2 - 5 } & \multicolumn{4}{c}{ Kapas } \\
& \% R & K/S & \% R & K/S \\
\cline { 2 - 5 } & 13,71 & 2,72 & 5,07 & 8,88 \\
\hline Tanpa post- & & & & \\
mordanting & 19,13 & 1,71 & 8,36 & 5,02 \\
$\mathrm{Al}_{2}\left(\mathrm{SO}_{4}\right)_{3}$ & 18,76 & 1,76 & 7,73 & 5,51 \\
$\mathrm{Ca}\left(\mathrm{OH}_{2}\right)_{2}$ & 12,53 & 3,05 & 4,00 & 11,53 \\
$\mathrm{FeSO}_{4}$ & & &
\end{tabular}

Pada Tabel 1, terlihat perbedaan mencolok nilai ketuaan warna dari kedua jenis sampel yang digunakan. Sampel kain sutera mempunyai nilai $\mathrm{K} / \mathrm{S}$ yang lebih tinggi daripada kapas, sedang \%R sebaliknya. Hal ini terjadi karena kain sutera mempunyai kemampuan berikatan dengan senyawa flavonoid hasil ekstraksi daun rami daripada kain kapas. Sutera mempunyai dua gugus yang dapat berikatan dengan anion zat warna dan kation logam yaitu gugus amino dan karboksil, sedangkan kapas hanya mempunyai gugus hidroksil. Gugus amino dan karboksil pada sutera mempunyai daya tarik yang kuat dengan anion zat warna dan kation logam. Anion zat warna dari flavonoid dan kation dari zat mordan juga dapat membentuk ikatan kompleks logam. Interaksi tersebut menghasilkan ikatan ion antara zat warna dengan serat sutera, logam dengan serat sutera, dan zat warna dengan logam seperti yang tergambarkan pada Gambar 2.27



-G-A-G-A-G-S-G-A-A-G--S-S-G-(A-G) - - $\mathbf{l}-$-T-

Gambar 2. Prediksi struktur ikatan mordansutera-flavonoid (quercetin) ${ }^{27}$

Selanjutnya penggunaan $\mathrm{FeSO}_{4}$ menjadikan nilai K/S yang paling tinggi dibandingkan dengan bahan post-mordanting lainnya. $\mathrm{FeSO}_{4}$ adalah jenis logam transisi. Ion logam transisi diketahui dapat berikatan kuat dengan molekul zat warna alam karena kemampuannya untuk membentuk koordinasi kompleks, dengan demikian 
menghasilkan warna yang lebih tua. Saat berikatan dengan serat, ion logam besi dari $\mathrm{FeSO}_{4}$ dapat membentuk koordinasi kompleks dengan molekul zat warna yang lebih besar daripada logam alumunium atau kapur. Akibatnya, beberapa sites koordinasi tetap kosong, pada saat tersebut gugus fungsional dari serat sutera seperti gugus amino dan karboksil dapat mengisi sites yang kosong. $\mathrm{FeSO}_{4}$ kemudian membentuk kompleks terner pada satu site dengan serat dan site lain dengan zat warna. Hal inilah yang mengakibatkan penyerapan zat warna yang lebih tinggi serta perubahan arah warna. ${ }^{28}$

Nilai kecerahan dapat dilihat dari $\Delta \mathrm{L}^{*}$ pada sistem ruang warna $L^{*} a^{*} b^{*}$. Semakin nilainya menjauhi nol maka warnanya akan semakin cerah ke arah putih. Sebaliknya, semakin nilainya mendekati nol atau sampai negatif (-) maka warnanya akan semakin tua ke arah hitam. Dari hasil pengujian kecerahan warna yang disajikan pada Tabel 2, terjadi perbedaan kecerahaan warna antara jenis kain sampel dan zat post-mordanting yang digunakan. Secara umum kain kapas memiliki nilai $\Delta \mathrm{L}^{*}$ kain yang di post-mordanting menggunakan $\mathrm{FeSO}_{4}$ jauh lebih negatif dibandingkan sampel yang menggunakan bahan post-mordanting lainnya.

Perbedaan arah warna ditunjukkan dengan notasi $\Delta \mathrm{a}^{*}$ dan $\Delta \mathrm{b}^{*}$ pada sistem ruang warna CIELab. Notasi $\Delta \mathrm{a}^{*}$ menyatakan warna-warna kromatik merah dan hijau.

Warna merah ditunjukkan dengan nilai notasi $\Delta \mathrm{a}^{*}$ postif $(+)$ dan warna hijau ditunjukkan dengan nilai notasi $\Delta \mathrm{a}^{*}$ negatif (-). Sedangkan untuk notasi $\Delta \mathrm{b}^{*}$ menyatakan arah warna kuning - biru. Warna kuning ditunjukkan dengan nilai notasi $\Delta \mathrm{b}^{*}$ positif $(+)$ dan warna biru ditunjukkan dengan nilai notasi $\Delta b^{*}$ negatif (-).

Pada Tabel 2, didapati semua nilai $\Delta \mathrm{a}^{*}$ dan $\Delta \mathrm{b}^{*}$ positif dengan nilai $\Delta \mathrm{a}^{*}$ dan $\Delta \mathrm{b}^{*}$ pada kain sampel yang menggunakan zat post-mordanting $\mathrm{FeSO}_{4}$ lebih rendah daripada $\mathrm{Al}_{2}\left(\mathrm{SO}_{4}\right)_{3}$ dan $\mathrm{Ca}(\mathrm{OH})$. Hal ini mengindikasikan bahwa pencelupan kain kapas dan kain sutera dengan menggunakan zat warna hasil ekstraksi daun rami menghasilkan warna dengan arah warna ke merah dan kuning. Penggunaan zat post-mordanting $\mathrm{FeSO}_{4}$ mempengaruhi arah warna menjadi kurang merah dan kurang kuning jika dibandingkan dengan penggunaan zat post-mordanting $\mathrm{Al}_{2}\left(\mathrm{SO}_{4}\right)_{3}$ dan $\mathrm{Ca}(\mathrm{OH})_{2}$.

Tabel 2. Data nilai uji beda warna pada kain sampel hasil pencelupan

\begin{tabular}{|c|c|c|c|c|c|c|c|c|}
\hline \multirow[t]{2}{*}{ Variasi } & \multicolumn{4}{|c|}{ Kain Kapas } & \multicolumn{4}{|c|}{ Kain sutera } \\
\hline & $\Delta \mathrm{L}^{*}$ & $\Delta \mathrm{a}^{*}$ & $\Delta \mathrm{b}^{*}$ & Hasil & $\Delta \mathrm{L}^{*}$ & $\Delta \mathrm{a}^{*}$ & $\Delta \mathrm{b}^{*}$ & Hasil \\
\hline $\begin{array}{l}\text { Post- } \\
\text { mordanting } \\
\mathrm{Al}\left(\mathrm{SO}_{4}\right)_{3}\end{array}$ & $-25,21$ & 3,62 & 9,68 & & $-27,07$ & 8,58 & 15,85 & \\
\hline $\begin{array}{l}\text { Post- } \\
\text { mordanting } \\
\mathrm{Ca}(\mathrm{OH})\end{array}$ & $-24,36$ & 3,89 & 8,60 & & $-29,39$ & 8,50 & 11,60 & \\
\hline $\begin{array}{l}\text { Post- } \\
\text { mordanting } \\
\mathrm{FeSO}_{4}\end{array}$ & $-31,7$ & 2,44 & 7,65 & & $-43,43$ & 3,01 & 2,02 & \\
\hline
\end{tabular}


Tabel 3. Data uji ketahanan luntur warna terhadap pencucian

\begin{tabular}{ccccccc}
\hline Variasi & \multicolumn{5}{c}{ Nilai perubahan dan penodaan warna sesuai skala abu } \\
\cline { 2 - 7 } & \multicolumn{5}{c}{ Kapas } & \multicolumn{4}{c}{ Sutera } \\
\cline { 2 - 7 } & $\begin{array}{c}\text { Perubahan } \\
\text { warna }\end{array}$ & $\begin{array}{c}\text { Penodaan } \\
\text { pada sutera }\end{array}$ & $\begin{array}{c}\text { Penodaan } \\
\text { pada wol }\end{array}$ & $\begin{array}{c}\text { Perubahan } \\
\text { warna }\end{array}$ & $\begin{array}{c}\text { Penodaan } \\
\text { pada sutera }\end{array}$ & $\begin{array}{c}\text { Penodaan } \\
\text { pada wol }\end{array}$ \\
\hline Tanpa Post & 3 & $4-5$ & $4-5$ & 4 & $4-5$ & $4-5$ \\
mordanting & & & & & & \\
$\mathrm{Al}_{2}\left(\mathrm{SO}_{4}\right)_{3}$ & $3-4$ & $4-5$ & $4-5$ & 4 & $4-5$ & $4-5$ \\
$\mathrm{Ca}(\mathrm{OH})$ & $3-4$ & $4-5$ & $4-5$ & 4 & $4-5$ & $4-5$ \\
$\mathrm{FeSO}_{4}$ & $3-4$ & $4-5$ & $4-5$ & 4 & $4-5$ & $4-5$ \\
\hline
\end{tabular}

\section{Analisis Uji Ketahanan Luntur Warna terhadap Pencucian}

Tabel 3 menunjukkan hasil uji ketahanan luntur warna terhadap pencucian. Berdasarkan data pada Tabel 3, hasil uji ketahanan luntur warna terhadap pencucian pada pencelupan kain kapas dan sutera menggunakan larutan ekstrak daun rami relatif baik. Hal ini ditunjukkan dengan nilai perubahan warna maupun penodaannya masih pada rentang nilai 3-4 hingga 4-5. Namun nilai perubahan warna pada sampel kain kapas lebih rendah daripada kain sutera. Sesuai dengan standar prosedur uji ketahanan luntur kain terhadap pencucian, pada saat diuji sampel kain mengalami kontak dengan larutan cuci dengan kondisi dan temperatur tertentu. Perubahan warna pada sampel kain kapas disebabkan karena flavonoid pada ekstrak daun rami ini memiliki afinitas yang lebih rendah dengan kain kapas daripada kain sutera sehingga tidak mempunyai kemampuan untuk membentuk ikatan kompleks yang lebih kuat, ${ }^{17}$ sehingga sebagian zat warna yang tidak terpostmordanting sempurna akan luntur dan larut bersama larutan cuci. Jika melihat dari nilai penodaannya, sisa zat warna tersebut tidak berpotensi untuk menodai kain jenis lainnya ketika proses pencucian aktual.

\section{Analisis Uji Ketahanan Luntur Warna terhadap Gosokan}

Pada penelitian ini dilakukan uji ketahanan luntur warna terhadap gosokan. Gosokan yang dilakukan adalah gosokan kering dan gosokan basah dengan menggunakan crockmeter serta hasilnya dinilai dengan skala abu-abu untuk penodaan warna (staining scale). Hasil uji ketahanan luntur warna terhadap gosokan disajikan pada Tabel 4.

Nilai penodaaan warna setelah dilakukan gosokan kering sama baik pada kain sampel kapas maupun pada kain sampel sutera. Namun nilai penodaan warna setelah dilakukan gosokan basah berbeda pada tiap-tiap jenis kain sampel dan lebih rendah dibandingkan nilai gosokan kering. Nilai yang lebih rendah ini kemungkinan disebabkan oleh adanya interaksi kain sampel dengan air. Air yang ditambah perlakuan gosokan serta tekanan akan menghidrolisa zat warna yang tidak berikatan secara sempurna pada permukaan kain sampel. Sisa-sisa zat warna di permukaan tersebut berpindah dan menempel pada permukaan kain gosokan sehingga terjadi penodaan warna pada kain gosokan tersebut. Seperti terlihat pada nilai penodaan warna kain sampel kapas dan sutera tanpa post-mordanting memperlihatkan nilai penodaan warna yang relatif rendah.

Tabel 4. Data uji ketahanan luntur warna terhadap gosokan

\begin{tabular}{|c|c|c|c|c|}
\hline \multirow[t]{3}{*}{ Variasi } & \multicolumn{4}{|c|}{$\begin{array}{c}\text { Nilai penodaan warna sesuai skala } \\
\text { abu }\end{array}$} \\
\hline & \multicolumn{2}{|c|}{ Kapas } & \multicolumn{2}{|c|}{ Sutera } \\
\hline & Kering & Basah & Kering & Basah \\
\hline $\begin{array}{l}\text { Tanpa Post- } \\
\text { mordanting }\end{array}$ & $4-5$ & $3-4$ & $4-5$ & $3-4$ \\
\hline $\mathrm{Al}_{2}\left(\mathrm{SO}_{4}\right)_{3}$ & $4-5$ & $3-4$ & $4-5$ & 4 \\
\hline $\mathrm{Ca}(\mathrm{OH})$ & $4-5$ & 4 & $4-5$ & 4 \\
\hline $\mathrm{FeSO}_{4}$ & $4-5$ & $3-4$ & $4-5$ & $3-4$ \\
\hline
\end{tabular}

\section{Analisis Uji Ketahanan Luntur Warna terhadap Sinar Matahari}

Pengujian kualitas hasil pencelupan berikutnya adalah pengujian ketahanan luntur warna terhadap sinar matahari. Pengujian ini dilakukan dengan mengamati adanya perubahan warna dari kain sampel dan kain standar (blue wool) setelah proses penyinaran. Penilaian perubahan warna dilakukan dengan membandingkan hasil uji dengan standar abu-abu perubahan warna (grey scale). Data hasil pengujian ditampilkan pada Tabel 5.

Tabel 5. Data uji ketahanan luntur warna terhadap sinar matahari

\begin{tabular}{lcc}
\hline \multirow{2}{*}{ Variasi } & \multicolumn{2}{c}{ Nilai perubahan warna } \\
\cline { 2 - 3 } & \multicolumn{2}{c}{ Kesuai skala abu } \\
\hline Tanpa & Putera \\
$\mathrm{Al}_{2}\left(\mathrm{SO}_{4}\right)_{3}$ & 2 & $2-3$ \\
$\mathrm{Ca}(\mathrm{OH})$ & 2 & $2-3$ \\
$\mathrm{FeSO}_{4}$ & 2 & 2 \\
\hline
\end{tabular}


Pada Tabel 5 tersebut, secara umum nilai perubahan warna kain sampel setelah penyinaran sinar matahari rendah. Pada jenis kain sampel kapas lebih rendah nilainya daripada kain sampel sutera. Rosenberg (2008) menyebutkan kain yang dicelup dengan zat warna alam yang berasal dari senyawa flavonoid mempunyai kemampuan tahan luntur terhadap cahaya yang terbatas. ${ }^{29}$ Terjadinya perubahan warna pada kain hasil pencelupan zat warna ekstraksi daun rami ini disebabkan oleh energi foton dari sinar. Energi foton dari sinar dapat mengurai senyawa organik, dalam hal ini flavonoid sehingga merusak dan memudarkan warnanya. Ketahanan luntur warna terhadap sinar dapat ditingkatkan dengan penambahan timah atau $\mathrm{FeSO}_{4}$ sebagai bahan post mordanting atau postmordanting pada proses pencelupan. ${ }^{30}$ Kain yang dipost-mordanting dengan $\mathrm{FeSO}_{4}$ membentuk ikatan kompleks logam transisi yang melindungi kromofor dari degradasi fotolitik. Foton-foton yang diserap oleh gugus kromofor membuang energi mereka dengan beresonansi dalam cincin enam gugus yang terbentuk, sehingga warna menjadi terlindungi. ${ }^{28} \mathrm{Hal}$ tersebut terbukti dengan hasil uji yang telah dilakukan. Seperti yang ditunjukkan pada Tabel 5, kain sampel yang menggunakan $\mathrm{FeSO}_{4}$ sebagai zat post-mordantingnya mempunyai nilai paling tinggi dibandingkan dengan kain sampel lainnya.

\section{Analisis Uji Proteksi UV}

Transmitan dan nilai UPF dari kain standar kapas, sutera, serta kain yang sudah dicelup menggunakan larutan ekstrak daun rami diukur mengunakan spektrofotometer JASCO V-750 pada rentang panjang gelombang $200-400 \mathrm{~nm}$. Nilai UPF dari tiap sampel kain ditentukan dari total spektra transmitan menggunakan persamaan (2) berikut:

$$
\mathrm{UPF}=\frac{\sum_{290}^{400} E_{\lambda} S_{\lambda} \Delta_{\lambda}}{\sum_{290}^{400} E_{\lambda} S_{\lambda} T_{\lambda} \Delta_{\lambda}}
$$

Keterangan

$\mathrm{E}_{\lambda}$ : Spektral eritermal relatif efektivitas

$\mathrm{S}_{\lambda}$ : Spektral radiasi sinar ultraviolet matahari

$\mathrm{T}_{\lambda}$ : Transimi spektral terukur dari kain

$\Delta_{\lambda}$ : Bandwidth/lebar pita dalam millimeter, dan $\lambda$ adalah panjang gelombang dalam nanometer

Nilai UPF yang dihasilkan diklasifikasikan sebagaimana yang ditunjukkan pada Tabel 6 berikut:
Tabel 6. Klasifikasi proteksi nilai UPF

\begin{tabular}{cc}
\hline Rentang Nilai UPF & Klasifikasi \\
\hline $0-15$ & No class \\
$15-24$ & Good \\
$25-39$ & Very Good \\
$40-50^{+}$ & Excellent \\
\hline
\end{tabular}

Hasil pengukuran nilai UPF ditunjukkan pada Tabel 7.

Tabel 7. Data uji UPF

\begin{tabular}{|c|c|c|c|c|c|}
\hline \multirow[t]{2}{*}{ No } & \multirow[t]{2}{*}{ Variasi } & \multicolumn{4}{|c|}{ Nilai UPF } \\
\hline & & $\begin{array}{l}\text { Kapas } \\
\text { (A) }\end{array}$ & Class & $\begin{array}{l}\text { Sutera } \\
\text { (B) }\end{array}$ & Class \\
\hline 1 & Standar & 2,5 & No class & 5,4 & No class \\
\hline 2 & $\begin{array}{l}\text { Tanpa Post- } \\
\text { mordanting }\end{array}$ & 8,8 & No class & 18,5 & Good \\
\hline 3 & $\mathrm{Al}_{2}\left(\mathrm{SO}_{4}\right)_{3}$ & 5,9 & No class & 13,7 & No class \\
\hline 4 & $\mathrm{Ca}(\mathrm{OH})_{2}$ & 5,9 & No class & 15,3 & Good \\
\hline 5 & $\mathrm{FeSO}_{4}$ & 10,6 & No class & 25 & $\begin{array}{l}\text { Very } \\
\text { Good }\end{array}$ \\
\hline
\end{tabular}

Berdasarkan Tabel 6 dan Gambar 3 dapat dilihat bahwa hasil pencelupan dengan menggunakan ekstrak daun rami berpengaruh signifikan terhadap nilai UPF. Nilai UPF pada sampel hasil pencelupan baik tanpa maupun dengan post-mordanting meningkat dibandingkan dengan sampel standar. Nilai UPF pada sampel kain sutera (B) lebih tinggi daripada sampel kain kapas (A). Secara klasifikasi nilai UPF, kain sutera yang dicelup dengan ekstrak daun rami berubah menjadi "Good" dan "Very Good" sedangkan pada sampel kain kapas tidak berubah. Berdasarkan penggunaan bahan post mordanting, penggunaan $\mathrm{FeSO}_{4}$ menjadikan nilai UPF yang paling tinggi pada kedua jenis sampel dibandingkan bahan yang lainnya. Adapun nilai UPF pada sampel A2 dan B3 (tanpa post mordanting) lebih tinggi dibandingkan dengan kain sampel dengan proses post mordanting menggunakan $\mathrm{Al}_{2}\left(\mathrm{SO}_{4}\right)_{3}$ dan $\mathrm{Ca}(\mathrm{OH})_{2}$. Perbedaan nilai tersebut kemungkinan disebabkan karena masih ada kandungan zat warna yang tidak berikatan dan menempel di permukaan kain sampel tanpa post-mordanting (A2 dan B2). Hal ini sudah dibuktikan dengan data ketuaan warna $\mathrm{K} / \mathrm{S}$ di atas. Di sisi lain kain sampel tanpa post-mordanting mempunyai durability yang lebih rendah, seperti pada data dari hasil uji ketahanan terhadap pencucian diatas. Dengan demikian, kemungkinan nilai UPF nya akan turun seiring dengan adanya pencucian pada kain sampel tersebut. 




Gambar 3. Grafik batang hasil uji nilai UPF

Hasil uji UPF pada sampel kain kapas dan sutera mengindikasikan bahwa pencelupan menggunakan zat warna hasil ekstrak daun rami berpengaruh signifikan pada peningkatan kemampuan kain tersebut dalam memproteksi dari radiasi UV. Hasil uji ini sekaligus menggambarkan kemampuan senyawa flavonoid yang terkandung dalam ekstrak daun rami dalam memberikan proteksi terhadap UV. Pada tanaman, flavonoid berperan melindungi tanaman dari radiasi sinar matahari UV dan menangkal UV yang dihasilkan oleh ROS (Reactive Oxygen Species). ${ }^{31}$ ROS ini adalah senyawa radikal bebas dari sinar UV yang bersifat oksidatif. Proses oksidasi yang terjadi karena paparan sinar UV dihambat oleh flavonoid melalui mekanisme transfer elektron. Gugus hidroksil pada flavonoid akan berperan sebagai penyumbang atom hidrogen ketika bereaksi dengan senyawa radikal bebas. ${ }^{32}$ Dengan mekanisme tersebut, ekstrak daun rami yang tercelup pada sampel kain kapas dan sutera dapat meningkatkan kemampuan kain tersebut dalam memproteksi dari radiasi UV.

\section{KESIMPULAN}

Daun rami dapat dimanfaatkan sebagai zat warna alam untuk mencelup bahan tekstil, terutama kain sutera karena mengandung senyawa flavonoid. Arah warna yang dihasilkan ke arah warna merah dan kuning. Hasil pencelupan kain kapas dan kain sutera menggunakan ekstrak daun rami memiliki ketahanan luntur warna terhadap pencucian dan gosokan yang relatif baik, namun ketahanan luntur warna terhadap sinar mataharinya relatif rendah. Ketahanan luntur warna terhadap sinar matahari dapat diperbaiki dengan penggunaan bahan post- mordanting $\mathrm{FeSO}_{4}$. Selain dapat mencelup bahan tekstil, ekstrak daun rami ini dapat memberikan fungsi lain. Fungsi tersebut adalah sebagai anti UV pada bahan tekstil. Pencelupan dengan ekstrak daun rami dengan bahan post-mordanitng $\mathrm{FeSO}_{4}$ secara signifikan meningkatkan kemampuan proteksi sinar UV hingga UPF 10,6 pada kain kapas dan UPF 25 untuk kain sutera. Pada kain sutera, peningkatan kemampuan proteksi anti UV paling tinggi dengan nilai UFP $25+$ dan dikategorikan sebagai "very good" atau "sangat baik".

\section{PUSTAKA}

1. Limited, W. P. Handbook of natural fi bres. (2012).

2. Ramie, B., For, P. \& Raw, P. Pulp rami putih sebagai bahan baku kertas. 45, 57-63 (2010).

3. Juhana, A. \& Hubeis, M. Prospek Ekonomi dan Strategi Pengembangan Kapas Rami Sebagai Bahan Baku Alternatif Industri Tekstil Skala Usaha Kecil ( Kasus Koppontren Darussalam , Garut - Jawa Barat ). 6, 111-116 (2011).

4. Novarini, E. \& Sukardan, M. D. the Potency of Ramie Fiber ( Boehmeria Nivea S . Gaud ) Technical Textile Industries. Arena Tekst. 30, 113-122 (2015).

5. Ilham, M. M. \& Istiqlaliyah, H. Pemanfaatan Serat Rami ( Boehmeria Nivea ) Sebagai Bahan Komposit Bermatrik Polimer (2019).

6. $\mathrm{Mu}$, L. et al. Assessment of ramie leaf ( Boehmeria nivea L . gaud ) as an animal feed supplement in P . R . China. (2019). 
7. Sudibyo, N. \& Mulyaningsih, S. Pengaruh proporsi limbah daun rami dalam konsentrat pakan lengkap terhadap pertumbuhan kambing. 72-79 (2004).

8. Kalikajar, K. \& Kalikajar, K. No Title. 201210 (2018).

9. Lan, T. P. Characterization Of $\square$-Amylase From Ramie Leaf. 3, 104-112 (2015).

10. Lee, H. L. A. K. J. Effects of Ramie Leaf Extract on Blood Glucose and Lipid Metabolism in db / db Mice. 57, (2014).

11. Noer, S., Pratiwi, R. D., Gresinta, E., Biologi, P. \& Teknik, F. Penetapan Kadar Senyawa Fitokimia ( Tanin , Saponin Dan Flavonoid Sebagai Kuersetin ) Pada Ekstrak Daun Inggu ( Ruta angustifolia L ). 19-29 (2018).

12. L, A. B., Yulianingtyas, A. \& Kusmartono, B. Optimasi Volume Pelarut Dan Waktu Maserasi Pengambilan Flavonoid Daun Belimbing Wuluh Optimization Of Solvent Volume And Maceration Time On Extraction Of Flavonoids From Averrhoa Bilimbi Leaves. 58-64. (2016)

13. Lee, D. G. et al. Quantitative analysis of the flavonoid content in the leaves of Boehmeria nivea and related commercial products. Nat. Prod. Sci. 21, 66-70 (2015).

14. Chen, Y. et al. Phytochemical profiles and antioxidant activities in six species of ramie leaves. PLoS One 9, (2014).

15. Keperluanindustri, U. Review : sumber dan pemanfaatan zat warna alam untuk keperluanindustri. 93-106 (2015).

16. Moiz, A., Ahmed, M. A., Kausar, N., Ahmed, K. \& Sohail, M. Study the effect of metal ion on wool fabric dyeing with tea as natural dye. J. Saudi Chem. Soc. 14, 69-76 (2010).

17. Mongkholrattanasit, R., Kryštůfek, J., Wiener, J. \& Studničková, J. Properties of wool and cotton fabrics dyed with eucalyptus, tannin and flavonoids. Fibres Text. East. Eur. 85, 90-95 (2011).

18. Rehman, F. et al. Dyeing of $\gamma$-irradiated cotton with natural fl avonoid dye extracted from irradiated onion shells ( Allium cepa ) powder. 92, 71-75 (2013).

19. Sangeetha, K., Gomathi, R. \& Bhuvaneshwari, M. Dyeing of Silk Fabric using Lemon Leaves Extract with the Effect of Different Mordants. Int. J. Innov. Res. Sci. Eng. Technol. (An ISO 3297, 4692-4697 (2007).
20. Kumar, C. S. S. \& Dhinakaran, M. Extraction and Application of Natural Dyes From Orange Peel and Lemon Peel on Cotton Fabrics. Int. Res. J. Eng. Technol. 4, 2008-2009 (2017).

21. Komalasari, M. \& Sunendar, B. Penggunaan $\mathrm{TiO}_{2}$ Partikel Nano Hasil Sintesis Berbasis Air Menggunakan Metoda Sol-Gel Pada Bahan Kapas Sebagai Aplikasi Untuk Tekstil Anti Uv. Arena Tekst. 28, 16-21 (2013).

22. Sugiyana, D. et al. Penyempurnaan Fungsional Anti Ultraviolet Pada Kain Poliester Menggunakan Seng Oksida Anti Ultraviolet Functional Finishing Of Polyester Fabric. (2019).

23. Rungruangkitkrai, N., Mongkholrattanasit, R., Wongphakdee, W. \& Studničková, J. Ecofriendly Dyeing and UV Protection Properties of Wool Fabric Using Natural Dye from Eucalyptus. Res. J. Text. Appar. 17, 29-37 (2013).

24. Zhou, Y., Yang, Z. Y. \& Tang, R. C. Bioactive and UV protective silk materials containing baicalin - The multifunctional plant extract from Scutellaria baicalensis Georgi. Mater. Sci. Eng. C 67, 336-344 (2016).

25. Koh, E. \& Hong, K. H. Preparation and properties of wool fabrics dyed with spent coffee ground extract. Text. Res. J. 89, 13-19 (2019).

26. Haerudin, A. \& Fitriani, A. Cotton And Silk Batik Coloring Using Indigofera Tinctoria Leaves From Ambarawa And Kulon Progo With Palm Sugar And Sugar Cane Drops As A Reducing Agents. (2019).

27. Deveoglu, O., Karadag, R., Spinella, A. \& Guzel, E. T. Examination of Dyeing Properties on Silk of Some Flavonoids by Spectroscopic Techniques. J. Nat. Fibers 0, 1-12 (2019).

28. Uddin, M. G. Effects of Different Mordants on Silk Fabric Dyed with Onion Outer Skin Extracts. J. Text. 2014, 1-8 (2014).

29. Rosenberg, E. Characterisation of historical organic dyestuffs by liquid chromatographymass spectrometry. Anal. Bioanal. Chem. 391, 33-57 (2008).

30. Gupta, D., Gulrajani, M. L. \& Kumari, S. Light fastness of naturally occurring anthraquinone dyes on nylon. Color. Technol. 120, 205-212 (2004).

31. Saewan, N. \& Jimtaisong, A. Photoprotection of natural flavonoids. J. Appl. Pharm. Sci. 3, 129-141 (2013). 
32. Injilia Wungkana, Edi Suryanto, L. Aktivitas Antioksidan Dan Tabir Surya Fraksi Fenolik Dari Limbah Tongkol Jagung (Zea Mays L.). Pharmacon J. Ilm. Farm. - UNSRAT Vol. 2 No. 04 Novemb. 2013 ISSN 2302 - 2493 2, 149-155 (2013). 